\title{
Between Competitiveness and Sustainability? Achievements and Dilemmas of Regional Policy in the Context of Economic Development of Rural Regions: the Case of Poland
}

\author{
Michał Dudek ${ }^{1}, \mathrm{PhD}, \mathrm{PhD}$ hab. Agnieszka Wrzochalska ${ }^{2}$, Prof. of IAFE-NRI
}

\begin{abstract}
:
A clear long-term economic trend is the concentration of capital and settlement. These processes increasingly include development centres located in cities and their functional areas. In turn, many peripheral areas, including rural areas, are subject to socio-economic marginalization. As a result, the inter-regional and intra-regional disparities in wealth and quality of life become more visible and deepen. Increasing spatial differences are confront with numerous scientific explanations and remedies, which usually are translated into different strategies and practices of regional policy. Regional policy actions assume a different scope, objectives, instruments of intervention and could be categorized as a policy based on the paradigm of competitiveness (polarisation) or sustainability. The aim of the paper was to determine the level of economic disparities between urban and rural regions in Poland in the context of assessment of implemented regional policy. In the paper selected approaches to supporting rural development in regional policy, namely the perspectives based on the paradigm of competitiveness and sustainability were characterised. The analyses carried out documented the differences in the intensity of support of EU Cohesion Policy tools per capita in favour of urban regions. Even though the value of financial support from EU funds was positively correlated with the level of regional development, there was no statistically significant impact of this intervention on the processes of economic convergence and divergence. The conclusions presented in the study were based on the analysis of the Eurostat data gathered for 72 Polish sub-regions in 2007-2015. For the purpose of the study the statistical methods (i.e. descriptive statistics, measures of economic convergence), as well as the content analysis of strategic documents were used.
\end{abstract}

Key words: rural regions, competitiveness, sustainability, economic development, regional policy

\section{Introduction}

High accumulation of capital and settlement growth in large urban centres is a regularity in economic development of countries and regions (Gorzelak, 2009). The concentration of the population and companies is accompanied by development of production and service activities with high added value, based on innovations which determine the achievement of competitive advantage and profits in our times. Different processes are observed in areas located around growth centres, especially the ones which are remote. As a rule, economic progress is not characterised by high dynamics there. On the contrary - many peripheral areas, most often rural ones, are characterised by structural barriers to development which, combined with market trends, face 
accumulated economic, social and environmental problems. In the long term, these phenomena reveal disproportions in the level of economic development and wealth of the inhabitants (Perrons, 2011). Thus, the spatial development model described is not universal. However, it is widespread enough to become an old subject of not only scientific reflection and public debate, but also the keystone of public policy interest, in particular regional and development policy. In this context, one can generally distinguish two approaches to regional development: based on the concept of competitiveness and sustainable development (Grosse, 2002, Bański, 2017).

The regional policy model implemented by the European Union (EU) can be treated as mixed. One of the objectives of this organisation is to strengthen economic, social and territorial cohesion and alleviate the disparities in development between the regions, in particular reduce the gap in the case of rural regions (Treaty on the Functioning..., 2016). This task is emphasised in many strategic and legal documents, and various instruments of economic policy are to serve its achievement. The EU Member States play an important role in determining the scale and directions of public intervention within the EU by defining their own development priorities and shaping the conditions and ways to achieve the set goals.

Poland is among the so-called new Member States with a relatively lower level of economic development. Since the accession to the EU, regional policy has been focused on economic catching-up in relation to the richest countries. Attempts to achieve these task were made primarily through public infrastructure investments, expenditures directed at improvement of the quality of the education and health care systems, cofinancing of projects focused on increasing qualifications and skills of labour resources, as well as supporting entrepreneurship and innovation. The above undertakings were mostly financed from the EU funds. Due to the large scale of interference of central and local authorities in economic processes, a question concerning the spatial effects of the initiatives undertaken, and in particular their impact on the level of economic development in the urban-rural dimension, arises. Therefore, the aim of this paper was to determine the inequities in the development of urban and rural regions in Poland in the context of assumed objectives and measures implemented within the framework of regional policy. The analyses covered the years 2007-2015, at the same time fell on the implementation of the EU financial perspective 2007-2013. The first part of the article specifies the methods and terminology used in the study and the sources of the analysed data. Subsequently, selected approaches to supporting rural development in regional policy were characterised. The next part of the text analyses the strategic assumptions of the Polish regional policy in the field of rural development and presents the research results on the effects of Cohesion Policy projects implemented between 2007 and 2015. The whole ends with a discussion and conclusions.

\section{Material and method}

This section analyses the key terms used in the paper and describes the data and research methods used for the purposes of the study. In regional policy as well as in analyses of the level of territorial development an important term is a rural region. This expression is usually understood as space outside the administrative boundaries of cities 
or areas consisting of a small urban centre with predominantly rural areas around it ${ }^{1}$. For the purpose of territorial categorisation, the indicators defining a role of agricultural sector in the economy, the level of urbanisation or the population density are often considered. Operationalisation of a rural region corresponding to this approach uses the Eurostat urban-rural typology (Eurostat, 2013). According to EU methodology, all EU regions at NUTS-3 level are divided into three types: urban, intermediate and rural ${ }^{2}$. In case of Poland in 201731 out of all 72 regions were classified as rural, 15 as urban and as 26 intermediate ${ }^{3}$.

As for the analysis presented here there are there important concepts: development, competitiveness and sustainability. All of mentioned phenomena could be understand ambiguously, and there are various ways of defining them. However, in the paper their economic aspect usually is considered. The development is referred to an increase in the GDP per capita of a given region ${ }^{4}$. In turn, the sustainability is about delivering a right amount of product, or using it to meet both current and future needs of societies. In the regional context this process includes the growth of a given area in order to preserve their long-term economic viability (Schleicher-Tappeser et al., 1999). Competitiveness is treated here as an ability of a region to offer an attractive and sustainable environment for firms and residents to live and work (Annoni et al., 2017).

The level of economic development of regions in Poland and its changes were analysed on the basis of statistical measures of variation (coefficient of variation), the Gini coefficient $^{5}$ and selected indicators of economic convergence. All these measures determined the economic differences between the analysed territorial units, expressed in GDP per capita. The conducted analyses took into account two measures of economic convergence: beta ( $\beta$-convergence) and sigma convergence ( $\delta$-convergence). ${ }^{6}$ As for determining beta convergence, this phenomenon is evidenced by a negative sign of the $b$ regression coefficient between the GDP per capita growth dynamics and its initial level in a given region (whereas divergence is recorded in the case of a positive sign of $b$ regression coefficient) ${ }^{7}$ (Wicki, 2012, Wasilewski, 2013 ). Additionally, for the purpose of identifying the impact of regional policy instruments on differences in the level of development of regions in Poland, the independent variable in the form of cumulative

1 The terms rural region and rural area are used interchangeably in the paper.

${ }^{2}$ In Polish public statistics these units are defined as subregions (NUTS-3 level).

3 On the other hand, they accounted for about a quarter of the total population in the EU-27 (Eurostat 2013).

${ }^{4}$ The terms development and economic growth are used interchangeably in the text.

5 The Gini coefficient assumes a value from 0 to 1 , where values closer to 0 mean smaller variations, and closer to 1 larger differences.

${ }^{6}$ Sigma convergence identifies the variability (dispersion) of the variable in the analysed period. It was determined on the basis of the analysis of the value of the coefficient of variation and the Gini coefficient of GDP per capita over time.

${ }^{7} \beta$-convergence was calculated using the regression function, where the independent variable was the natural logarithm from the level of GDP per capita in 2007, and the dependent variable was the natural logarithm of dynamics of GDP per capita in 2007-2015. In the assessment of the level of beta convergence, in addition to the assessment of the regression coefficient, the $\beta$ parameter called convergence coefficient was used (if $\beta>0$ there is convergence, when $\beta<0$ divergence occurs); it was calculated according to the formula: $\beta=-\ln (1+b) / T$, where $b$ means the regression coefficient, and $T$ the time between the first and the last observation (Wasilewski, 2013). 
value of funds from EU Cohesion Policy instruments per capita in 2007-2015 was added to the previously estimated regression model. In this case, the estimated equation was:

$\ln \left(\Delta y_{i t}\right)=a+b \ln y_{i, t-1}+\gamma Z_{i t}+\varepsilon_{i t}(1)$

where:

describe the level and rate of growth of GDP per capita for the region $i$ in the period $t$, $Z$ meant the value of EU Cohesion Policy funds per capita affecting the level or growth of GDP per capita,

$\varepsilon$ is the rest of the equation,

$a, b$ and $y$ are the estimated regression coefficients.

The premises of regional policy in Poland was analysed and evaluated on the basis of selected strategic documents on regional development which had an impact on public interventions in 2007-2015. These documents included following texts: Krajowa Strategia Rozwoju Regionalnego 2010-2020 (KSRR 2010-2020, Krajowa Strategia..., 2010), National Strategic Reference Framework 2007-2013 in support of growth and jobs. National Cohesion Strategy (NSRO, National Strategic..., 2007), Koncepcja Przestrzennego Zagospodarowania Kraju 2030 (KPZK 2030, Koncepcja Przestrzennego..., 2012), Strategia Zrównoważonego Rozwoju Wsi, Rolnictwa i Rybactwa na lata 2010-2020 (SZRWRiR 2010-2020, Strategia Zrównoważonego..., 2012) oraz Strategia Rozwoju Kraju 2007-2015 (SRK 2007-2015, Strategia Rozwoju..., 2006). The data to illustrate the changes in development of regions in Poland and its differentiation were taken from the Eurostat database(GDP, the number of population). The information about the use of funds from the EU budget through the Structural Funds (European Regional Development Fund - ERDF, European Social Fund - ESF and Cohesion Fund - CF) were obtained from the SIMIK IT system (SIMIK National IT System) designed to collect and aggregate basic data on operational programmes cofinanced by EU funds and management and monitoring of their implementation in Poland at the country, regional and local level. ${ }^{8}$

\section{Support of socio-economic development of rural regions: premises and limitations}

When considering the spatial developmental differences, two groups of standpoints are formulated within which different views on the reasons for economic inequalities and ways of solving them are expressed (Table 1). The first one is based on the paradigm of competitiveness, where the differences between territorial units are treated as a natural result of of market mechanisms (Gorzelak 2009, Lovering, 2015). These include, for example, theories of competitive advantage, growth poles, geographical growth centres, core and periphery, or theories based on neoclassical growth models (Grosse, 2002). The

${ }^{8}$ Data on Cohesion Policy measures for NUTS-3 regions should be treated as approximate data. The SIMIK system did not include information on how the funds were allocated between territorial units. This is why it uses a translation algorithm that is based on the locations of project implementations registered in applications and grant agreements and assumes a uniform distribution of project amounts into individual administrative units. Therefore, the presented results are approximate and are subject to certain errors (Wpływ członkostwa..., 2014). 
above-mentioned perspectives in the most general terms emphasise that developmental gaps result from differences in quality of labour and capital inputs (human capital, innovation) as well as the productivity of production factors (Tokarski, 2007). Spatial economic distances are not, according to the theories based on the assumptions of competitiveness, a negative thing. On the contrary, they favour the optimal allocation of resources and economic progress, because firstly, in the long term, with the right investment rate, it is possible for relatively poorer units, including peripheral and rural areas, to catch up with wealthier regions (the catching-up effect) (Bal-Domańska, 2011). Secondly, it is assumed that solutions developed in growth centres which increase the productivity of production factors tend to spread to other areas. Concepts based on the idea of competitiveness and polarisation and diffusion mechanism of development of regions also draw attention to the fact that public intervention should be limited due to the visible differences in economic growth. The support of the authorities for the regions should amount to the creation of legal and institutional conditions conducive to business activity and the promotion of social and spatial mobility. According to the position views described, in special cases the provision of financial assistance, e.g. in relation to poorer regions, should be based on effectiveness and efficiency criteria and directed mainly towards the supply side.

Table 1. Concepts of competitiveness and sustainability in regional development: a comparison

\begin{tabular}{|c|c|c|}
\hline region & competitiveness paradigm & sustainability paradigm \\
\hline aim & $\begin{array}{l}\text { creating structural conditions conducing } \\
\text { development }\end{array}$ & $\begin{array}{l}\text { limiting the developmental gaps } \\
\text { between regions }\end{array}$ \\
\hline $\begin{array}{l}\text { ts of } \\
\text { at }\end{array}$ & $\begin{array}{l}\text { technology, productivity of production } \\
\text { factors }\end{array}$ & $\begin{array}{l}\text { lack of government intervention, } \\
\text { market failures }\end{array}$ \\
\hline $\begin{array}{l}\text { consequences } \\
\text { of regional } \\
\text { disparities }\end{array}$ & $\begin{array}{l}\text { long-term economic convergence, } \\
\text { optimal allocation of resources }\end{array}$ & $\begin{array}{l}\text { economic crises, } \\
\text { economic divergence }\end{array}$ \\
\hline instruments & $\begin{array}{l}\text { legal and institutional tools in favour of } \\
\text { business activity and social mobility }\end{array}$ & public investments \\
\hline $\begin{array}{l}\text { examples } \\
\text { theories } \\
\text { studies }\end{array}$ & $\begin{array}{l}\text { growth poles, geographical growth } \\
\text { centres, core and peripheries, neoclassical } \\
\text { growth theories }\end{array}$ & $\begin{array}{l}\text { neoendogenous development, } \\
\text { innovative milieu, flexible production } \\
\text { agglomeration }\end{array}$ \\
\hline
\end{tabular}

Source: own elaboration.

According to the views which fit into the paradigm of sustainable regional development, on the other hand, a policy based on the competitiveness of regions de facto supports strong economic entities or companies with high growth potential, generally located in metropolises. As a result, the economic distance of companies and communities from the neighbouring and peripheral areas to growth centres is deepening. The paradigm of sustainable regional development shared the idea of market failures (Table 1). According to this standpoint, lack of institutional regulations of markets and the lack of support for demand and a local export base result in economic crises (O'Neill, 2011). Therefore, regional policy should be active in stimulating development, especially of relatively poorer areas, among others, through investment in technical and social infrastructure, the provision of assistance to economic entities, undertaking public 
and private projects to reduce the risk entailed by large projects. Thus, the approach based on the balancing of development recognises the possibility of influencing economic processes, and the alleviating of interregional and intra-regional gaps in prosperity is perceived as a feasible goal (Griffith-Jones, Cozzi, 2016). Different concepts can be put into place as part of regional studies supporting the sustainable development paradigm, e.g. theories of endogenous or neo-endogenous development, innovative milieu or flexible production agglomeration (Grosse, 2002). In practice, the assumptions of competitive and sustainable regional development in a pure form are rarely implemented in the actions of public authorities of countries and regions. The currently adopted model of regional policy is most often the result of two indicated approaches with an emphasis placed on one of them (Hadyński, 2015).

\section{Regional policy in Poland: between competitiveness and sustainability paradigm}

In recent years, in Poland, especially after the accession to the EU, the importance of regional policy has increased. This domain was included in the national system of strategic governance for development, its institutional system of implementation was outlined along with the methods of monitoring and evaluation, and the basic mechanism for the coordination of objectives and projects between the central and local government authorities was determined. At the same time, a large number of regulations and strategies were formulated, which did not support the reconstruction of the directions of planned measures. The analysis of documents related to regional development indicates, however, that while creating the principles, priorities and ways of intervention of the regional policy, the primary focus was on urbanised areas rather than on rural areas. Putting emphasis on large cities was supposed to foster the improvement of competitiveness and the catching-up of the development distance of the national economy and its individual segments in the regions in relation to the developed countries. An example of such an approach were documents of the KPZK 2030, and the KSRR 2010-2020, which specified the most important objective of the regional policy as the use of potential of the largest cities resulting in the creation of economic growth and employment (innovation) in metropolises: Major urban centres, in particular those with the largest number of metropolitan functions, are focal points for activity and fulfil functions that have impact on economic and civilisation growth rate of the entire country, as well as of individual regions. International status of such urban centres is an important measure of country overall position on the continent and in the world. In this respect, Polish cities significantly fall behind cities in other Member States of the European Union, in particular those in the west and north of Europe (Koncepcja Przestrzennego..., 2011). It was also noted that stimulation of the progress dynamics in large urban centres would bring positive economic effects on functionally linked areas and peripheral areas. The basis for these claims was the conviction about the importance of the spatial diffusion mechanism of beneficial economic phenomena: From the perspective of building regional competitiveness and efficient use of their whole area, it is important not only to support the continuous improvement of competitiveness of growth centres, but also to create conditions for the use of development potential of the remaining, as large as possible part of specific regions. This would be done through strengthening the capacity to absorb and diffuse development processes in areas outside 
the functional areas of voivodeship centres, i.e. sub-regional and local centres, rural areas (Strategia Rozwoju..., 2010).

Following the emphasis of improvement of competitiveness and the role of metropolises in regional development processes, the analysed strategic documents tried to take into account the principle of sustainability, noting the need to prevent excessive disproportions in the spatial dimension: There are still significant asymmetries in the quality of life... between rural and urban areas, as well as differences between individual rural areas. The assessment of rural development suggests the need to enhance the civilisation level in the countryside, strengthen development potential of local centres, develop public services, fully use the ICT networks, improve the quality of educational facilities, revitalise cities and towns, and develop all forms of innovation... (Strategia Zrównoważonego..., 2012). The alleviating of differences was to take place mainly through support for restructuring processes in rural areas (facilitating occupational and spatial mobility, restructuring of agriculture, investments in technical infrastructure), increasing of access to public services (increasing supply and quality of educational, training, medical, communication, municipal, cultural and environmental services) and fostering closer links between cities (National Strategy..., 2010, Koncepcja Przestrzennego..., 2011).

Recognition of the inclination for the polarisation of economic growth and the preference for promoting the competitiveness of regions through investments in cities was reflected in documents having a direct impact on the implementation of the national regional policy in 2007-2015, carried out with the use of Cohesion Policy funds, i.e. the SRK 2007-2015, and above all the NSRF (Strategia Rozwoju..., 2006, National Strategic..., 2007). Similarly to other analysed studies, the course of action defined for the last studies was support of stronger territorial units, emphasising the significance of the processes of spreading of economic growth to rural areas. In practice, despite the declared objective of counteracting the marginalisation of rural regions, the adopted criteria for the division of funds, especially in the regional aspect, have de facto translated into concentrations of support in urbanised units. ${ }^{9}$

\section{Development of rural regions in Poland in the context of implementation of EU Cohesion Policy}

Eurostat data suggested that the level of development of regions in Poland, measured by the GDP per capita ratio, varied. In 2015, for rural regions, this value amounted to EUR 8.1 thousand, for intermediate regions EUR 9.6 thousand, and for urban areas EUR 15.3 thousand. Spatial developmental differences resulted mainly from the economic structure and gaps in productivity levels in their respective branches. Urban regions included the largest Polish cities (Warsaw, Katowice, Poznań, Wrocław, Tricity), which are the location of the most profitable service and industrial sectors, including in particular entities with foreign capital. These areas have been concentrating large private and public investments and have been the traditional direction of settlement

9 The principles of allocation of EU founds at the regional level took into account the share of the population of region in the total population of Poland to a decisive extent ( $80 \%$ ), and the level of wealth and unemployment to a much lesser extent (National Strategic..., 2007). 
for a long time. Intermediate regions, on the other hand, with a significantly lower level of development, have formed big cities (such as: subregions of Częstochowa, Olsztyn, and Wałbrzych) and areas functionally linked to metropolises, where the functioning of profitable and advanced companies was often accompanied by restructuring processes of traditional sectors. The relatively lowest value of GDP per capita has been noted in rural regions, consisting mostly of areas used for agriculture and small and medium-sized towns, usually grouping small businesses and activities with low added value (subregions of Siedlce, Chełm and Zamość, Przemyśl, and Leszno).

Regardless of the clear development distancesgaps and a serious world economic crisis, in 2007-2015, there was an increase in GDP per capita in all types of regions in Poland. It varied from $34 \%$ to $36 \%$. An increase in this indicator was primarily the result of favourable economic conditions (average annual GDP dynamics amounted to 3.6\%), which is associated primarily with an increase in consumption. The growing average total consumption was also strengthened by the good situation on the labour market (drop in unemployment rate from $8.5 \%$ to $6.9 \%$ ) and growing wages. In the analysed period, economic recovery was also associated with high activity in basic types of economic branches, an upward trend in international trade in favour of export, and effective gross expenditure on fixed assets.

In 2007-2015, the increasing level of GDP per capita in rural regions (from EUR 6.0 thousand to EUR 8.1 thousand) and intermediate regions (from EUR 7.1 thousand to EUR 9.6 thousand) could indicate both the spread of development trends from the growth centres, and progress generated on the basis of own resources. Nevertheless, the analysed data and statistical indicators showed that interregional development distances in Poland slightly increased. At the same time, it should be noted that the research results do not give rise to unambiguous conclusions. First of all, in 2015, in rural areas GDP per capita was lower by EUR 7.2 thousand compared to urban areas and by EUR 1.5 thousand compared to intermediate regions. Eight years earlier, these differences were lower and amounted to EUR 5.4 thousand and EUR 1.1 thousand, respectively. In comparative terms, however, the indicated discrepancies between rural areas and other regions remained at the same level. Secondly, the analysis of the processes of convergence of regions using the regression model showed a positive correlation between the GDP per capita growth dynamics and the initial level of this indicator (Table $2)$. The beta coefficient in the considered equation was positive (0.046), and the calculated $\beta$-convergence coefficient (convergence rate) was negative and amounted to (0,043). The quoted values would indicate the process of divergence in development of Polish regions. However, the lack of statistical significance of the regression coefficient does not allow formulating a conclusion about the occurrence of this phenomenon.

Table 2. Estimations results of $\beta$-convergence model ${ }^{*}$ for regions in Poland, 2007-2015

\begin{tabular}{ll}
\hline Specification & Regions \\
\hline $\ln$ GDP per capita & 0.046 \\
\hline & $\mathrm{p}=0.162$ \\
\hline Constant & 4.810 \\
\hline
\end{tabular}




\begin{tabular}{ll}
\hline & $\mathrm{p}<0.001$ \\
\hline$\beta$ coefficient & \\
(speed of convergence) & -0.043 \\
\hline Number of observations & 72 \\
\hline R-squared & 0.034 \\
\hline Adjusted R-squared & 0.020 \\
\hline Standard error & 0.076 \\
\hline $\mathrm{F}$ & $2.000(1-70)$ \\
\hline
\end{tabular}

Note: In model the natural logarithms of variables: X (PKB per capita in region in 2007) and $Y$ (change in PKB per capita growth) ware used.

* Change in GDP per capita at current market prices 2015/2007.

Source: own calculations based on Eurostat data.

The processes of growing differences in the level of economic development of regions in Poland was documented by the results of the analysis of the value of the coefficient of variation and the Gini coefficient of GDP per capita (Figure 1). Between 2007 and 2015, the value of the former coefficient increased, although slightly, from 0.403 to 0.419 , and the value of the latter increased from 0.178 to 0.193 . It should be noted that the relatively largest development disparities with the smallest dynamics of changes in this area were recorded in the group of urban regions (in the considered period, the coefficient of variation fluctuated from 0.35 to 0.38 ). In the group of rural regions, on the other hand, differences in GDP per capita were much smaller (the coefficient of variation ran from 1.8 to 2.7 ), although the scale of their growth in time was relatively the largest.

In 2007-2015, an important factor driving the economy were financial resources allocated for the implementation of the Cohesion Policy, being the basis for the implementation of the national regional policy. In general, the total amount of public funds allocated for the implementation of projects under five programmes managed at the national level, one supra-regional programme for eastern Poland and 16 regional programmes was EUR 85.6 billion (of which EUR 67.3 billion were funds from the EU budget)..$^{10}$

Figure 1. Gini coefficient and coefficient of variation of GDP per capita in regions in Poland, 2007-2015

${ }^{10}$ In addition, an important stream of transfers directed at rural areas were instruments of the Common Agricultural Policy (CAP) and funds of the European Fisheries Fund (EUR 0.7 billion). In 20072015, funds from the EU budget for the implementation of the CAP in Poland amounted to EUR 28.2 billion and included direct payments and expenditure on rural development (Nurzyńska, 2016). 


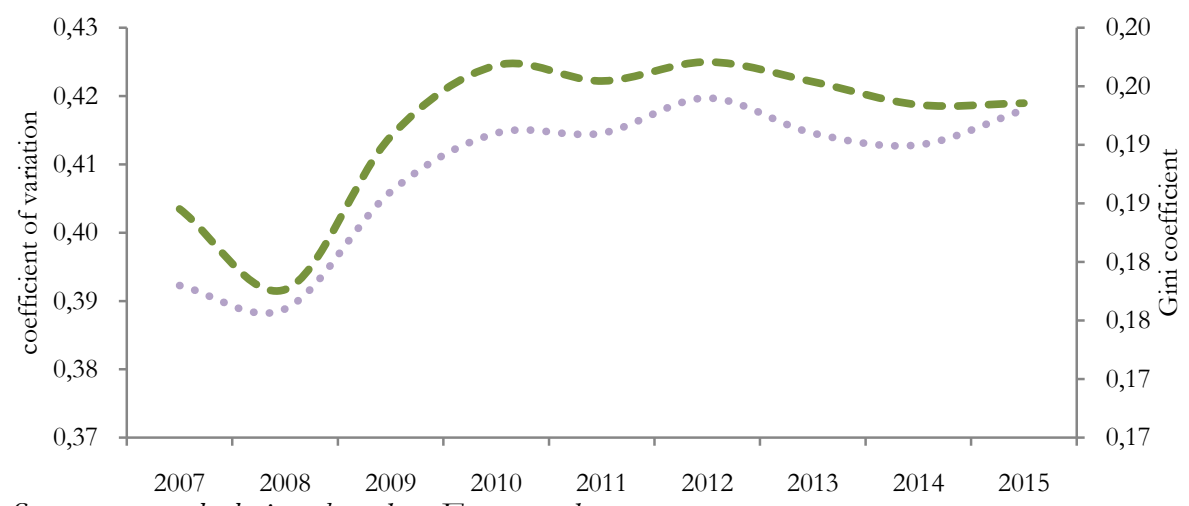

Source: own calculations based on Eurostat data.

These transfers supported projects of construction and modernisation of technical infrastructure (mainly transport infrastructure and infrastructure for environmental protection), projects aimed at increasing employment, supporting the education system, health care, administration and initiatives aimed at development of activity by companies and scientific units. The available data indicated that the distribution of EU Cohesion Policy support in Poland was diverse. The average value of money from the EU funds per one inhabitant in rural areas amounted to about EUR 1.2 thousand, while in urban regions it was EUR 1.7 thousand and in intermediate regions EUR 1.5 thousand. ${ }^{11}$ Thus, the intensity of support from the Cohesion Policy was positively correlated with the level of economic development of Polish regions (the correlation coefficient was 0.350). On this basis, the impact of these funds on the identified divergence processes could be expected. The results of the $\beta$-convergence model estimation indicated a positive relation between the GDP per capita dynamics and the amount of support from the Cohesion Policy per capita in the regions. ${ }^{12}$

\section{Discussion and conclusions}

In the paper, the GDP per capita was used as a measure of the regions' development. The literature emphasises its limitations regarding the narrow recognition of this phenomenon. It is argued that this typically quantitative indicator does not take into account important economic phenomena (such as domestic work, the value of free time, external effects important for the environment and society) and does not reflect adequately the level and quality of life, which are an important element of economic progress (Block, 1990). Therefore, a number of studies were undertaken using alternative indicators (see: Fitoussi et al., 2009). At the same time, GDP per capita is characterised by the advantages associated with high availability, uniform methodology of calculation, the possibility of making comparisons over time and space, as well as simplicity and good representativeness for the economy. These reasons determined the use of this measure

11 The above-mentioned amounts were converted at the exchange rate EUR 1=PLN 4.2.

12 The beta coefficient in the considered equation was positive (0.026), and the calculated $\beta$ convergence coefficient (convergence rate) was negative and amounted to $(-0,003)$. 
for the analysis of the level of diversity of regional development. In economic research, epistemological and methodological doubts are also often raised by the distinction of space into urban and rural. It is believed that economic and technological changes called into question the arbitrary classifications of territories made on the basis of administrative boundaries. Typologies based on functions, connections and potential of given areas are proposed as a relatively more adequate division of areas. Irrespective of these arguments, the conducted research assumed the importance of the categorisation of regions into urban and rural resulting from differences in population size and density and the significance of agricultural production in a given regional economy. The methodology for classifying regions according to Eurostat used in the paper taking into account directly the former criterion is widely used in public statistics and scientific research.

Numerous discussions focus on terms: development, sustainability and competitiveness, often mentioned in the text. The arguments indicating the vagueness and multifaceted nature of these concepts are quite true. The article uses classic definitions which were to reflect both the quantitative dimension of economic phenomena (GDP per capita as an indicator quantifying development and the level of its regional differentiation), and the qualitative perspective of theories describing the causes and consequences of economic disparities and ways for public policy to respond to them.

The achievements of economic sciences and regional studies include numerous theories explaining inequalities in the wealth of individual territorial units. For the purposes of the research, a number of concepts were synthesised and grouped, which proved useful in analysing the approach used in the EU and Polish regional policy. Regardless of the simplifications made, the categorisation presented here into the perspectives based on the paradigm of competitiveness and sustainability reflected the differences in premises and ways of implementing pro-development interventions of public authorities. However, it must be assumed that in general it is hard to unambiguously assign measures and strategies of countries and organisations in the area of spatial economic disparities to one of the defined views. Usually, there are complex premises and undertakings that can highlight the philosophy of development, whose keystone is to support the competitiveness of regions or achievement of a balance between them.

Prior to Poland's accession to the EU, the strategic documents pointed to the need to balance development processes in different regions, although the need to support areas and entities with the highest potential was more strongly emphasised, which was to be related to the effectiveness and efficiency of the intervention. Rural areas were not given much attention (Bański, 2017). The situation changed after 2004. The accession to the EU was accompanied by an increase in the activity of public institutions in the area of regional development strategies and concepts. Since then, relatively greater importance has been attached to rural issues. However, it was considered primarily through the prism of metropolises and cities as functional areas in relation to them (Bański, 2017). It should be emphasised that the strategic documents analysed in the paper demonstrated the dilemma between polarisation and balancing of development. Nevertheless, it was perceived as a false problem, the solution to which lies in the appropriate support for the growth centres (Boni, 2009). For the aforementioned reasons, it should be held 
that the analysed strategies of regional development policy in Poland in 2007-2015 supported the competitiveness paradigm relatively more.

The preference for metropolises and cities was also reflected in the practice of the EU Cohesion Policy implemented in Poland. Both the distribution of financial resources and the shape of its individual instruments are favourable to the concentration of interventions in the regions with the highest level of urbanisation and served the entities operating within them (Modranka, 2018). At the same time, the phenomenon of interception of support should be associated with the market mechanism which usually rewarded companies and organisations with extensive experience and significant financial potential and human resources. In addition, in the context of focusing significant financial resources through the CAP on rural areas, the orientation of the Cohesion Policy on cities seemed to be reasonable and justified.

The analyses carried out documented the differences in the intensity of support of Cohesion Policy tools per capita in favour of urban regions. Even though the value of financial support from EU funds was positively correlated with the level of regional development, there was no statistically significant impact of this intervention on the processes of economic convergence and divergence. Observed high economic development in all regions in Poland between 2007 and 2015 was mainly the result of good economic situation and was spatially relatively balanced. Thus, it strengthens historically shaped regional economic disparities. Additionally, the analysis of data with the use of statistical measures of variability and the Gini coefficient demonstrated a slight tendency towards divergence of regional development in Poland.

\section{References}

Annoni P., Dijkstra L., Gargano N. (2017). The EU Competitiveness Index 2016. Brussels: European Commission.

Bal-Domańska B. (2011). Ekonometryczna identyfikacja $\beta$ konwergencji regionów szczebla NUTS-2 państw Unii Europejskiej. Acta Universitatis Lodziensis. Folia Oeconomica 253, 9-23.

Bański J. (2017). Rozwój obszarów wiejskich. Warszawa: PWE.

Block F. (1990). Postindustrial Possibilities. A Critique of Economic Discourse. Los Angeles: University of California Press.

Boni M. (2009). Polska 2030. Wyzwania rozwojowe. Warszawa: KPRM.

Clocke, P. (2006). Conceptualizing Rurality. In: Clocke, P., Marsden, Mooney, P. (eds.) The Handbook of Rural Studies. London, Thousand Oaks, New Dehli: Sage, 18-28.

Eurostat (2013). Updated urban-rural typology: integration of NUTS 2010 and the latest population grid. 2010. Statistics in focus 16/2013.

Fitoussi J-P.. Sen A.. Stiglitz J. (2009). Report by the Commission on the Measurement of Economic Performance and Social Progress. https://www.insee.fr/en/information/2662494.

Gorzelak G. (2009). Fakty i mity rozwoju regionalnego. Studia Regionalne i Lokalne 2(36). Warszawa: Euroreg. 5-27.

Grosse G.T. (2002). Przegląd koncepcji teoretycznych rozwoju regionalnego. Studia Regionalne i Lokalne 1(8)/2002. Warszawa: Centrum Europejskich Studiów Regionalnych i Lokalnych UW, 25-48.

Griffith-Jones S.. Cozzi G. (2016). Investment-led Growth: A solution to European Crisis. In: Jacobs M.. Mazzucato M. Rethinking Capitalism. Economics and Policy for sustainable and inclusive growth. Chechister: Wiley-Blackwell. 119-133.

Hadyński J. (2015). Regionalna konkurencyjność obszarów wiejskich, Poznań: Wydawnictwo Uniwersytetu Przyrodniczego w Poznaniu.

Koncepcja Przestrzennego Zagospodarowania Kraju 2030 (2011). Załącznik do uchwały Rady Ministrów z dn. 13.12.2011 (poz. 252). 
Krajowa Koncepcja Rozwoju Regionalnego 2010-2020: regiony, miasta, obszary wiejskie (2010). Dokument przyjęty przez Radę Ministrów 13.07.2010.

Lovering J. (2011). The New Regional Governance and the Hegemony of Neoliberalism. In: Pike A., Rodriguez-Pose, Tomaney J. (eds.) Handbook of Local and Regional Development. London, New York: Routledge, 581-594.

Marini M.B., Mooney P.H. (2006). Rural economies. In: Clocke, P., Marsden, Mooney, P. (eds.) The Handbook of Rural Studies. London, Thousand Oaks, New Dehli: Sage, 91-103.

Modranka E. (2018). Wpływ polityki spójności na realną konwergencję wewnątrzregionalną w Polsce w latach 2007-2013 (2018). Warszawa: seminarium Euroreg, 17.05.2018.

National Strategic Reference Framework 2007-2013 in support of growth and jobs. National Cohesion Strategy. (2007). Warszawa: Ministry of Regional Development.

Nurzyńska I. (2016). Polska wieś I rolnictwo jako beneficjenci funduszy Unii Europejskiej. In: Wilkin J., Nurzyńska I. (eds.) Polska wieś 2016. Raport o stanie wsi. Warszawa: Wydawnictwo Naukowe Scholar, 107-128.

OECD (2013). Urban-rural Partnerships. An Integrated Approach to Economic Development. OECD Rural Policy Reviews. Paris: OECD.

O’Neill P. (2011). The Language of Local and Regional Development. In: Pike A., Rodriguez-Pose, Tomaney J. (eds.) Handbook of Local and Regional Development. London, New York: Routledge, 551-568.

Perrons D. (2011). Regional Disparities and Equalities: Towards a Capabilities Perspective? In: Pike A., Rodriguez-Pose, Tomaney J. (eds.) Handbook of Local and Regional Development. London, New York: Routledge.

Schleicher-Tappeser R., Lukesch R., Strati F., Sweeney G.P., Thierstein A. (1999). Instruments for Sustainable Regional Development. The INSURED project. Final Report. Freiburg: Eures.

Strategia Rozwoju Kraju 2007-2015 (2006). Warszawa: Ministerstwo Rozwoju Regionalnego.

Tokarski T. (2007). Teoretyczne podstawy przyczyn zróżnicowania rozwoju gospodarczego. In: Piasecki R. (red.) Ekonomia rozwoju, Warszawa: PWE.

Wasilewski A. (ed.) (2013). Skuteczność instrumentów polityki regionalnej i strukturalnej oddziałujących na rozwój przedsiębiorczości. Warszawa: IAFE-NRI.

Weber B.A., Freshwater D. (2016). The Death of Distance? Networks, the Cost of Distance and UrbanRural Interdependece. In: Shucksmith M., Brown D.L. (eds.) Routledge International Handbook of Rural Studies. London and New York: Routledge, 154-164.

Wicki L. (2012). Konwergencja czy dywergencja w zakresie stosowania nasion kwalifikowanych w Polsce (analiza regionalna). Roczniki Naukowe Stowarzyszenia Ekonomistów Rolnictwa i Agrobiznesu, $1(14), 539-544$.

Treaty on the Functioning of the European Union (2016). Dz. Urz. UE 2016 C 202. art. 174.

Wpływ członkostwa Polski w Unii Europejskiej i realizowanej polityki spójności na rozwój kraju (2014). Warszawa: Ministerstwo Infrastruktury i Rozwoju. 